OPEN ACCESS

Edited by:

Mario Barletta

Departamento de Oceanografia da

Universidade Federal de Pernambuco

(UFPE), Brazil

Reviewed by:

Monica F. Costa

Universidade Federal de Pernambuco,

Brazil

Riaan Van Der Merwe Khalifa University, United Arab

Emirates

*Correspondence:

Maria Cristina Fossi

fossi@unisi.it

Specialty section:

This article was submitted to

Marine Pollution

a section of the journal

Frontiers in Marine Science

Received: 29 January 2018

Accepted: 02 May 2018

Published: 23 May 2018

Citation:

Fossi MC, Panti C, Baini M and Lavers

$J L$ (2018) A Review of

Plastic-Associated Pressures:

Cetaceans of the Mediterranean Sea and Eastern Australian Shearwaters as

Case Studies. Front. Mar. Sci. 5:173.

doi: 10.3389/fmars.2018.00173

\section{A Review of Plastic-Associated Pressures: Cetaceans of the Mediterranean Sea and Eastern Australian Shearwaters as Case Studies}

\author{
Maria Cristina Fossi ${ }^{1 *}$, Cristina Panti ${ }^{1}$, Matteo Baini ${ }^{1}$ and Jennifer L. Lavers ${ }^{2}$ \\ ${ }^{1}$ Department of Physical Sciences, Earth and Environment, University of Siena, Siena, Italy, ${ }^{2}$ Institute for Marine and Antarctic \\ Studies, University of Tasmania, Hobart, TAS, Australia
}

Impacts of debris on marine fauna occur throughout the marine ecosystems, with adverse impacts documented on over 1,400 species; impacts can be divided into those arising from entanglement, and those from ingestion. Ingestion of, and entanglement in, debris has been documented in over $60 \%$ of all cetacean species. Seabirds are also impacted by debris predominately through entanglement and ingestion, with the number of species negatively impacted increasing from 138 to 174 over the past two decades. In the marine environment, cetaceans and seabirds are widely regarded as reliable sentinels due to their position near the top of the marine food web, conspicuous nature, and reliance on marine resources; for this reason, this paper is focused on seabirds and cetaceans as sentinels of ocean change. In particular, two case studies are considered in relation to different levels of environmental anthropogenic impact: the cetaceans of the Mediterranean Sea and seabirds of eastern Australia. Here we describe two recent studies used to diagnose the toxicological stress related to debris-associated pressures in cetaceans and seabirds. These studies highlight the diversity and scale of impacts being felt by marine species and the role these organisms can play in our society as charismatic sentinels of ocean health. Seabirds and marine mammals are exposed, in these key areas, to a variety of adversities that potentially decrease their survival or reproductive success. These include weather, food shortages, predators, competitors, parasites, disease, and human-induced effects and plastic pollution. Each factor affects seabirds and marine mammals in a different way, but more importantly, factors can also interact and create impacts far greater than any one factor alone. The Australian and Mediterranean case studies presented here emphasize the need to consider multiple sources of mortality when developing management plans for the conservation of vulnerable species.

Keywords: anthropogenic impacts, apex predator, cumulative pressures, marine debris, plastic pollution, seabirds, cetaceans 


\section{WILDLIFE AND PLASTIC INTERACTION: THE CASE STUDIES OF CETACEANS AND SEABIRDS}

Records of interactions between anthropogenic marine debris (hereafter simply "debris") and wildlife have been increasing rapidly in recent decades. In the marine environment alone, the number of species reported to be affected by debris increased by more than 159\% during 1995-2015 (from 267 to 693 species; Laist, 1997; Gall and Thompson, 2015) and has since doubled in only 2 years to around 1,465 species (http://litterbase.awi.de/ interaction_detail; date accessed: 17 April 2018). The ingestion of debris, one of the most common interaction, can occur either directly when an animal mistakes an item for prey (DonnellyGreenan et al., 2014; Lavers and Bond, 2016), indirectly through the consumption of prey that contain debris (Setälä et al., 2014; Rochman et al., 2017), or through off-loading of debris from adults to young through regurgitation (Carey, 2011).

Ingestion of debris can contribute to false feelings of satiation, blockages of the digestive track, reduction of fat stores and body condition, and can ultimately lead to death (van Franeker and Law, 2015). Worryingly, plastic items contain chemical additives such as UV stabilizers and flame retardants which are compounded at the time of manufacture (Rani et al., 2015), or adsorb to the surface of items once in the marine environment (Mato et al., 2001; Rochman et al., 2013). Such chemicals include persistent organic pollutants (POPs), like dichlorodiphenyltrichloroethane (DDT), polychlorinated biphenyls (PCBs), and heavy metals like lead and cadmium (Massos and Turner, 2017), many of which are known neurotoxins or endocrine disruptors (Sussarellu et al., 2016). Once ingested, debris items can act as a vector, or pathway, for potentially toxic chemicals to bioaccumulate across all levels of aquatic food webs (Lavers et al., 2014; Bakir et al., 2016; Gutow et al., 2016). These contaminants become bioavailable through leaching into digestive fluids and transferring to the tissues (Tanaka et al., 2015). Biomagnification is also a concern, particularly for high-trophic predators such as seabirds, sharks, and whales (Santana et al., 2017).

In light of the increasing pressure and diversity of factors faced by marine wildlife in recent years, the main objective of this paper was to review the growing threat posed by marine plastics and associated chemicals on two charismatic groups of marine organisms: the cetaceans of the Mediterranean Sea and seabirds of eastern Australia. These two case studies were selected as the regions are geographically distinct, yet the species considered are all top predators that experience similar threats (e.g., plastic debris). Additionally, the species included in this paper are often considered umbrella species, providing valuable insights for other marine life that inhabit these threatened ecosystems.

\section{CETACEANS AND SEA BIRDS AS SENTINELS OF OCEAN HEALTH}

Indicator species or "sentinels" have been used as a tool to communicate the health of ecosystems for decades (Zacharias and Roff, 2001), and when used correctly, they can synthesize large quantities of information on pollution, fish abundance, and other natural and anthropogenic changes (Cairns, 1988; Burger and Gochfeld, 2004). In the marine environment, cetaceans and seabirds are widely regarded as reliable sentinels due to their position near the top of the marine food web, conspicuous nature, and reliance on marine resources (Furness, 1997; Durant et al., 2009; Schwacke et al., 2013; Fossi and Panti, 2017).

Sentinel species with physiology and/or diets similar to those of humans, such as cetaceans, may provide an early indication of potential adverse health effects and insight into the toxic mechanisms of a given hazardous agent (Schwacke et al., 2013). Multiple stress factors stemming from the bioaccumulation of anthropogenic contaminants combined with infectious diseases, invasive species, food depletion, and climate change pose potential hazards to both marine mammal and seabird populations worldwide (Jenssen, 2005; Poloczanska et al., 2013; Dirzo et al., 2014; BirdLife International National Audubon Society, 2015). For this reason, attention is focusing on seabirds and cetaceans as charismatic sentinels of ocean change.

Cetaceans, in particular, have similar mammalian physiology to humans and are long-lived, top predators, so they can be effective indicators for chronic or slow developing pathologies that are more difficult to detect in human populations exposed to lower levels of the same hazard (Bossart, 2011). In the past, cetaceans were not generally considered to be useful sentinel species because of their protected status and the difficulty of obtaining tissue samples. However, after several large-scale mortality events of marine mammals worldwide, concern from the scientific community has led to the establishment of a global biomonitoring programs to collect data to help elucidate temporal and geographic trends, including for plastic pollution (IWC, 2013). To this end, marine mammal tissue banks and marine mammal stranding networks were established worldwide. They have proven to be very useful tools for evaluating temporal and geographic trends of environmental exposure to contaminants, biotoxins, pathogens and recently plastic debris, using standardized collection, banking, and analysis techniques for marine mammal tissues (Schwacke et al., 2013). However, an alternative option to monitoring the health status of marine mammals, also related to the impact of plastic additives, is the relatively non-invasive method of sampling skin biopsies from freeranging animals (Fossi and Marsili, 1997; Fossi and Panti, 2017).

The following section describes two recent studies which diagnose the toxicological stress related to plastic-associated pressures in cetaceans and seabirds (plastic pollution, bioaccumulation of anthropogenic contaminants combined with infectious diseases, food depletion, and climate change). These studies, originating from environments exhibiting contrasting levels of anthropogenic pressure, highlight the diversity and scale of impacts being felt by marine species and the role these organisms can play in our society as charismatic sentinels of ocean health. 


\section{IMPACT OF MARINE DEBRIS ON CETACEANS}

Impacts of debris on marine fauna occur throughout the marine ecosystems, with adverse impacts documented on over 800 species (Gall and Thompson, 2015; Kühn et al., 2015). For marine mammals, impacts can be divided into those arising from entanglement, which can result in injury, drowning or strangulation, and those from ingestion, with pathology ranging from no discernible impact through to blockage of the digestive tract, suffocation and starvation (Sheavly and Register, 2007). Sub-lethal effects may compromise feeding and associated malnutrition, disease and reduced reproduction, growth and longevity (Moore et al., 2013). New data suggests when the dimension of the items ingested by marine fauna range from millimeter to nanometer in size (i.e., micro- debris $1 \mu \mathrm{m}-5 \mathrm{~mm}$ and nano-plastics $<1 \mu \mathrm{m}$, GESAMP, 2016), this can lead to inflammation, damage of the tissues at the cellular level, or altered molecular pathways (Mattsson et al., 2015, 2017; Pedà et al., 2016) . Baulch and Perry (2014) and Kühn et al. (2015) reviewed the data on plastic ingestion and entanglement rates available for cetaceans, showing an increase in the number of cases being reported over the last five decades. A total of 130 papers/documents were published from 1965 to January 2018, 44 on entanglement and 86 on ingestion of debris by cetaceans. Only 2 out of the 13 cetacean families analyzed have not interacted with debris, and ingestion appears to be the most common, occurring in over $58 \%$ of all cetacean species, including species employing a variety of feeding techniques throughout the water column (Fossi et al., 2018a; Figure 1).

In contrast, entanglement events have only been documented in $\sim 30 \%$ of cetacean species (Figure 1). The majority of entanglements for cetaceans are in ghost or active fishing gear (Baulch and Perry, 2014). Cetaceans tend be entangled around their neck, flippers and flukes (Moore et al., 2013; van der Hoop et al., 2014).

However, for the ingestion of debris, the number of records does not reflect the magnitude of the issue, due to low detection rate and difficulty in retrieving and analyzing specimens. Sixtythree percent of the 89 species of cetaceans (excluding the possibly extinct Lipotes vexillifer according to Committee on Taxonomy 2017) have been reported to be affected by debris. Items ingested are most commonly plastic $(46 \%$ of all items ingested) and range in size from small fragments $(<5 \mathrm{~mm}$, Besseling et al., 2015; Lusher et al., 2018) to large sheets of plastic and netting over one meter long (Jacobsen et al., 2010; de Stephanis et al., 2013). However, globally, the paucity and homogeneity of data prevented a robust identification of whether, at a species level, there are certain cetacean species particularly prone to ingesting debris. This is mainly due to the difficulties in performing such analysis in these species and the lack of harmonized and standard protocols (e.g., many entanglement events or cases of debris ingestion are not reported). Seventy per cent of the documents analyzed were published after 2000 , although only in the last few years were standardized protocols applied, and this can affect the reliability of the results reported.

\section{Ingestion of Microplastics by Cetaceans}

The study of microplastic ingestion by cetaceans is a challenging task, due to the difficulty in obtaining accurate samples during necropsies and analyzing large volumes (e.g., from large cetaceans). Few studies have directly identified microplastics in the digestive tracts of stranded cetaceans. Applying standard protocols for the detection and identification of microplastics in the digestive tract (Lusher et al., 2015), microplastics were found throughout the stomach/intestine of seven odotontocetes species: Ziphius cavirostris, Delphinus delphis, Stenella coeruleaolba, Phocoena phocoena, Orcinus orca, and Tursiops truncatus (Lusher et al., 2018; van Franeker et al., 2018). Only one study on Mysticetes, a stranded humpback whale (Megaptera novaeangliae), recorded the presence of microplastic in its intestines, including fragments, and threads (Besseling et al., 2015).

There are multiple possible routes of microplastic uptake, including direct ingestion from the water column while feeding, inhalation at the air-water interface, or via trophic transfer from prey items (IWC, 2013). Uptake of microplastics has been demonstrated in zooplankton species such as copepods and euphasiids (Kühn et al., 2015; Fossi et al., 2018b), which are some of the main prey of baleen whales and may thus be a source of secondary transfer of debris to cetaceans.

\section{MARINE DEBRIS IMPACT ON MEDITERRANEAN CETACEANS: THE CASE STUDY OF THE MEDITERRANEAN FIN WHALE}

The Mediterranean Sea is one of most affected areas by debris in the world: $115,000-1,050,000$ particles $/ \mathrm{km}^{2}$ are estimated to float in the Mediterranean Sea (Fossi et al., 2012; UNEP/MAP, 2015; Suaria et al., 2016). Plastics and other polymer materials are the most common types of marine debris, representing some $80 \%$ of debris found on sea surface (Fossi et al., 2017). As larger pieces of plastic debris fragment into smaller pieces, the abundance of microplastics in marine habitats increases. Despite the recent advances made within the framework of the Barcelona Convention Regional Plan for Marine Litter Management in the Mediterranean and the EU Marine Strategy Framework Directive (Descriptor 10), there is still a long way ahead to tackle debris in the Mediterranean and reduce the risks posed to Mediterranean marine wildlife.

Recent studies suggest that debris, including micro-plastics and chemical additives (e.g., phthalates), tend to accumulate in pelagic areas in the Mediterranean (Panti et al., 2015; Pedrotti et al., 2016), indicating a potential overlap between debris accumulation areas and endangered species' feeding grounds (Figure 2; Fossi et al., 2016). This fact highlights the potential risks posed to endangered, threatened and endemic species of Mediterranean biodiversity. In one of the most biodiverse area of the Mediterranean Sea, the Pelagos Sanctuary, cetaceans coexist with high human pressure and are subject to a considerable amount of plastic debris, including microplastics (Collignon et al., 2014; Cózar et al., 2014). 


\section{Interaction with debris}

A

Documented Not Documented

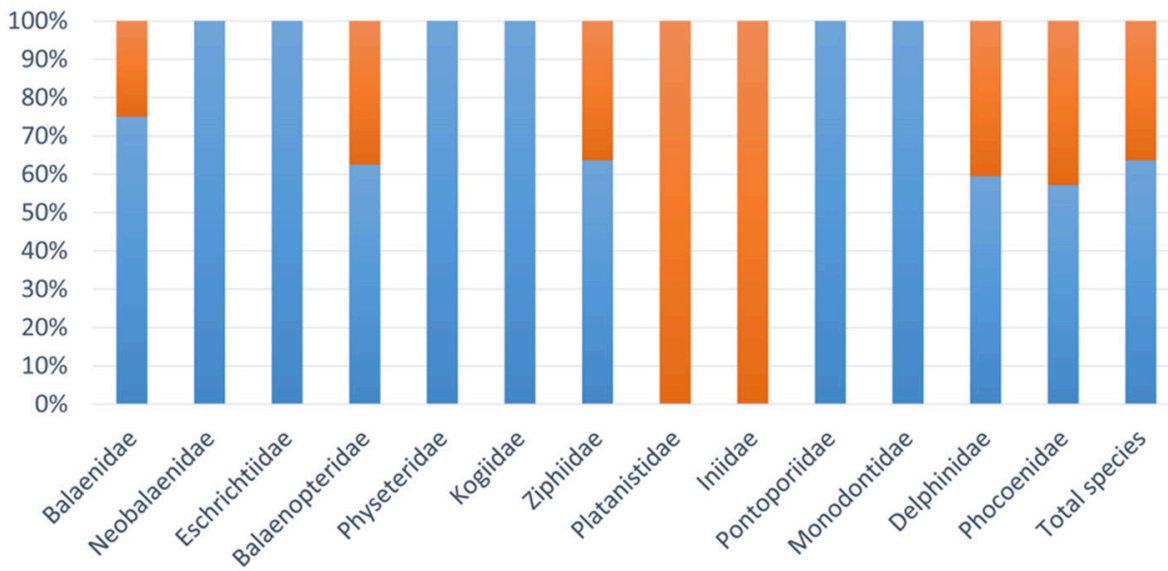

Entanglement

B

nocumented not Documented

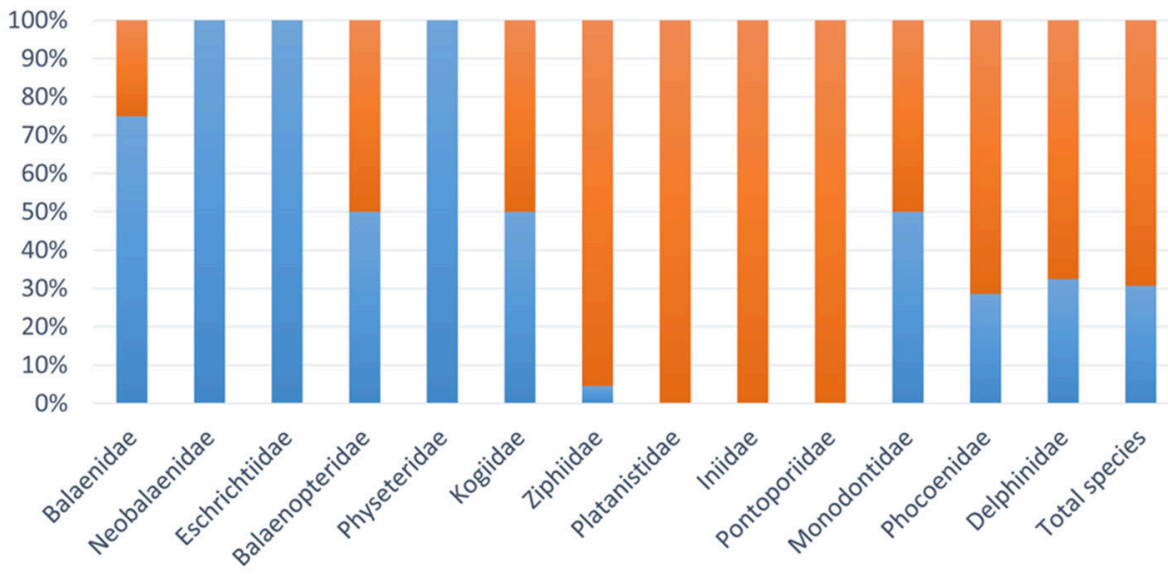

Ingestion

C Documented $\quad$ Not Documented

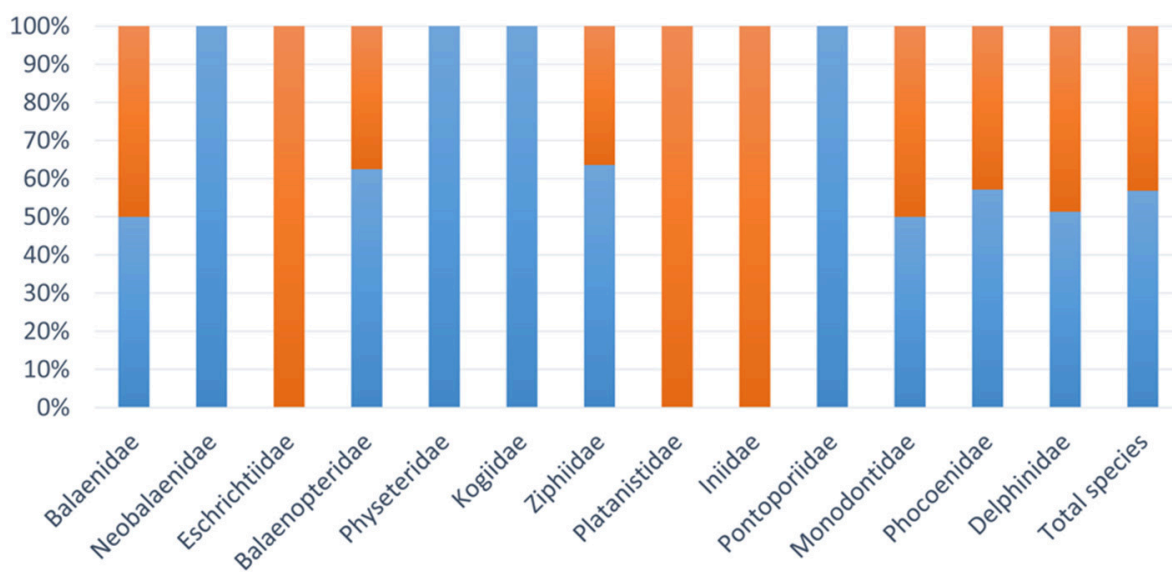

FIGURE 1 | Percentage of studied species for debris in relation to the total number of species per family in the order Cetaceans. (A) Interaction with debris including both entanglement and ingestion; (B) percentage of species with documented/not documented entanglement; (C) percentage of species with documented/not documented ingestion. 


\section{Environmental pollution}

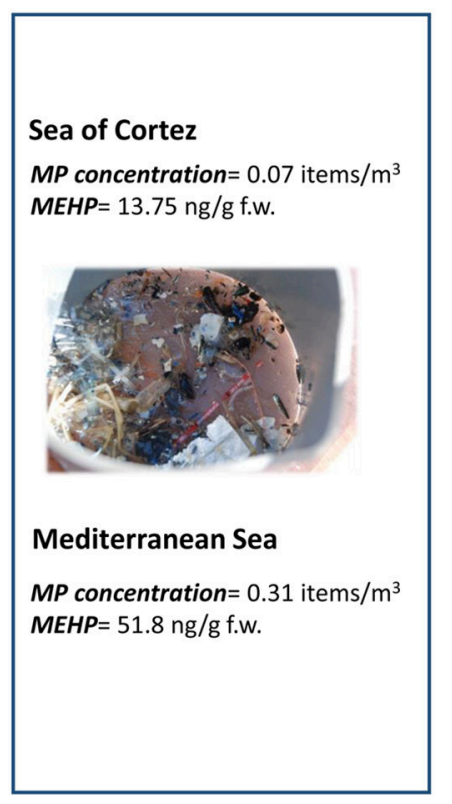

Biological responses

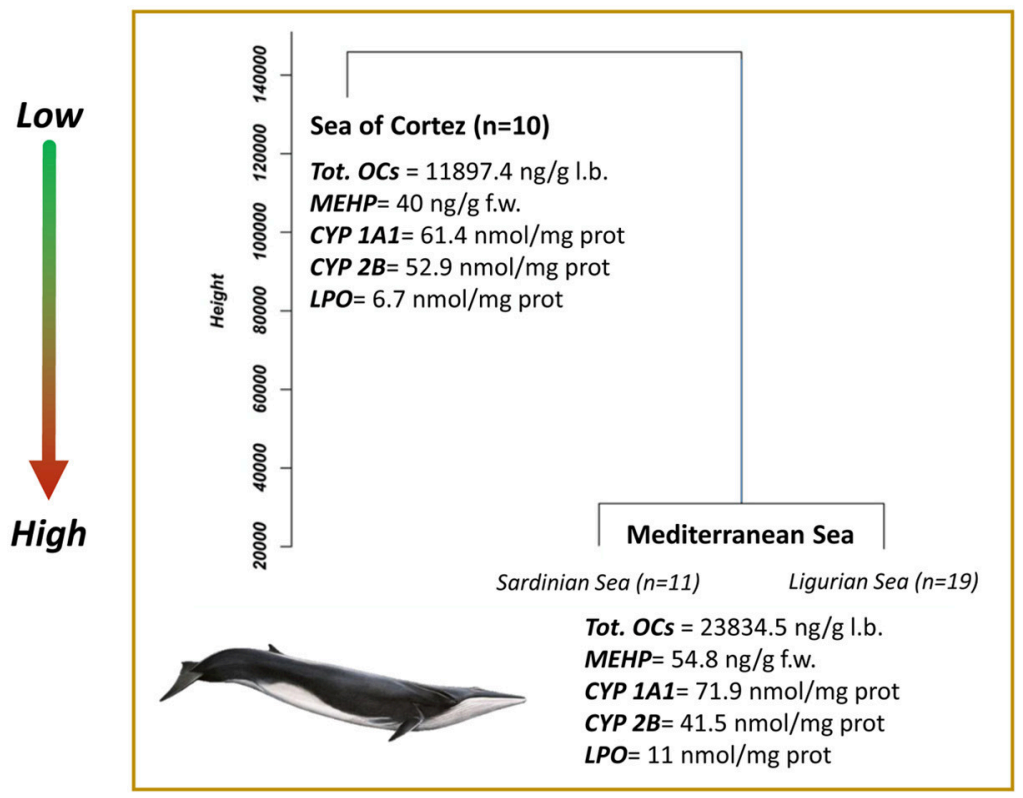

FIGURE 2 | Comparison between microplastic concentration and phthalates in zooplankton samples and the cluster dendrogram resulting from the analysis of biological parameters (mean values) measured on fin whale skin biopsies from the Sea of Cortez (Mexico) and Mediterranean Sea (Sardinian and Ligurian Sea). MP, microplastic; MEHP, mono-(2-ethylhexyl) phthalate; CYP1A1, cythocrome P450 1A1; CYP2B, cythocrome P450 2B; LPO, lipid peroxidation; OCs: organochlorine compounds (modified from Fossi et al., 2016).

Fin whales (Balaenoptera physalus) forage on the dense aggregations of krill in the water column and near the surface, engulfing an average of $71 \mathrm{~m}^{3}$ of water per mouthful (Goldbogen et al., 2007). These whales are potentially exposed to the ingestion of debris as a result of their filter-feeding activity. The Mediterranean fin whale has therefore been estimated to potentially consume more than 3,000 microplastic particles per day, along with associated persistent, bioaccumulative and toxic (PBT) chemicals (Fossi et al., 2014). Using phthalates (a common plastic additive that leaches from plastic debris) as a tracer of microplastic uptake, Fossi et al. (2014) found that concentrations of the phthalate metabolite and organochlorines were markedly higher in the fin whale compared to another filterfeeders living in the same area, the basking shark (Cetorhinus maximus). The authors attributed this to a difference in the total plankton consumed daily and excretory activity of the fin whales, in particular, the potential excretion of such contaminants through the gills in fish vs. bioaccumulation in adipose tissue in cetaceans. Particularly high levels of microplastics have been documented in the Ligurian Sea, the summer feeding ground of the Mediterranean fin whale, in the same order of magnitude as the North Pacific Gyre (Cózar et al., 2015).

The interactions between cetaceans and micro-debris items has also been investigated in free-ranging fin whales, comparing populations living in two semi-enclosed basins, the Mediterranean Sea and the Sea of Cortez (Gulf of California) (Fossi et al., 2016). Fin whales are resident both in the Mediterranean and the Sea of Cortez. As a result, fin whales are exposed to a high potential risk of micro-debris ingestion in their feeding grounds due to the ingestion of contaminated prey and the direct ingestion of floating debris items. This species can therefore function as a critical indicator of the microplastic contamination across an entire basin (Fossi and Panti, 2017). In this case study, a considerably higher abundance of micro-debris and plastic additives were demonstrated in zooplankton samples from the Pelagos Sanctuary of the Mediterranean Sea compared to samples from the Sea of Cortez.

Given the abundance of plastics in the Mediterranean environment (Fossi et al., 2016), high concentrations of PBT chemicals, and biomarker responses detected in the biopsies of Mediterranean whales compared to whales inhabiting the Sea of Cortez, the exposure of Mediterranean whales to micro-debris because of direct ingestion and consumption of contaminated prey appears to pose a major threat to the health of fin whales in this region. The temporal and regional ecotoxicological differences support the hypothesis that the fin whale is as a large-scale indicator of the impact of microplastics and related contaminants in pelagic environments, as well as a sentinel of the integrity of the marine food chain on the basin scale.

In a recent paper, Fossi et al. (2017) investigated the possible overlap between micro-debris, meso-debris (from 5 to $25 \mathrm{~mm}$ ) and macro-debris $(>25 \mathrm{~mm})$ accumulation areas and the fin whale feeding grounds in the pelagic Specially Protected Area of Mediterranean Importance, the Pelagos Sanctuary. Models of ocean circulation and potential fin whale habitat were merged to compare debris accumulation with the presence of whales. Field data on the abundance of micro-, meso-, and macro-debris, and on the presence of cetaceans were collected simultaneously. The resulting data were compared, as a multi-layer, with the simulated distribution of plastic concentration and the whale habitat model. 
Field and model observations on marine debris distribution and accumulation areas overlapped the fin whale feeding habitat, paving the way for a risk assessment of fin whale exposure to microplastics. The approaches used in this paper, and by Darmon et al. (2017) for sea turtles predict where species will be the most affected by plastic debris, enabling the identification of sensitive areas for species-specific ingestion to be defined, and providing a basis for the mapping of areas to be protected. Based on data or outputs from models on both macro- or micro-plastics, and species distribution, from plankton to large vertebrates, the same approach could be largely used to predict areas where the risk of ingestion occurs and the possible consequences on biodiversity.

\section{IMPACT OF MARINE DEBRIS ON SEABIRDS}

Seabirds are also impacted by debris through entanglement and ingestion, with the number of species negatively impacted increasing from 138 to 174 over the past two decades (Laist, 1997; Gall and Thompson, 2015). The considerable threat plastic poses to marine biodiversity has led to it being recognized as a problem at international, national and regional levels (e.g., Australian Threat Abatement Plan for the Impacts of Marine Debris on Vertebrate Marine Life, 2009). The pervasive and ubiquitous nature of plastic debris has also led to the recommendation that plastic be listed as hazardous waste (Rochman et al., 2013). In Australia, at least seven species of pelagic seabird (Family Diomedeidae and Procellariidae) have either a significant proportion of their breeding population, or important foraging areas, located in this region. Of these, six (86\%) species are known to ingest plastic debris (Ryan, 1987; Carey, 2011; Verlis et al., 2013), one of which-the Flesh-footed Shearwater (Ardenna carneipes)is perhaps the most heavily impacted seabird, globally (Lavers et al., 2014).

\section{THE CASE STUDY OF MARINE DEBRIS AND ASSOCIATED CHEMICALS IN FLESH-FOOTED SHEARWATERS}

For some seabird species, foraging within debris accumulation zones (e.g., the North Pacific subtropical gyre near Hawaii) has been shown to positively influence the volume of debris consumed by these birds (Young et al., 2009), suggesting individuals that forage in more pristine areas may experience lower risk of debris-associated impacts. This pattern has also been observed for fin whales (Fossi et al., 2016). However, an exception to this is the Flesh-footed Shearwater.

\section{Ingestion of Plastic by Flesh-Footed Shearwaters}

The world's largest population of Flesh-footed Shearwaters ( $\sim 16,000$ pairs; Reid et al., 2013) breeds on the remote, UNESCO
World Heritage listed Lord Howe Island, New South Wales $\left(31.5^{\circ} \mathrm{S}, 159.1^{\circ} \mathrm{E}\right)$ with adult birds foraging almost exclusively in the central Tasman Sea off eastern Australia (Reid, 2010). These birds exhibit some of the highest debris ingestion rates of any marine vertebrate (90\% of birds contain an average of 17 pieces weighing $\sim 3$ g; Lavers et al., 2014), which suggests there may be significant quantities of debris floating within the east Australian marine environment. However, compared to the North Pacific Gyre which is estimated to contain $\sim 334,200$ items $\mathrm{km}^{2}$ (Moore et al., 2001), the Tasman Sea is relatively pristine with only 2483,711 items $\mathrm{km}^{2}$ recorded during recent surveys (Rudduck et al., 2017).

The ingestion of debris by Flesh-footed Shearwaters, and associated exposure to chemicals, are now thought to contribute to the ongoing decline of this species (Lavers et al., 2014; Lavers, 2015). Increased quantities of ingested debris have been linked with higher concentrations of metals in shearwater fledglings (80-90 days old), and have also been shown to significantly reduce fledgling body mass and wing length, which is thought to lower juvenile survival by $\sim 11 \%$ (Lavers et al., 2014). Recent high resolution images generated using an X-ray fluorescent microprobe (XFM) have highlighted the distribution and uptake of elements, such as arsenic, in shearwater feathers that may have originated from ingested debris items (Howell et al., 2012, 2017). Examination of plastic items from these same birds using XMF suggests the surface is enriched with potentially hazardous elements, including arsenic and mercury, likely adsorbed from the surrounding aquatic environment (Howell et al., 2014). Once ingested, these plastic items may leach contaminants into an animal's blood stream (Tanaka et al., 2015). Preliminary data also suggest shearwater fledglings which are fed debris by parent birds may be exposed to increased concentrations of PCBs (Lewis, 2016).

Young seabirds cannot regurgitate ingested plastics for the majority of the nestling period ( $\sim 12$ weeks in the Procellaridae), during which time they are at greater risk from the effects of ingested debris than adults (Carey, 2011). While adult birds offload the majority of debris items to their chicks during the breeding season, individuals may still be exposed to chemicals, either through their prey or while foraging and collecting items at-sea (i.e., short-term exposure). In Flesh-footed Shearwaters, the mean concentration of mercury in feathers $(6.04 \pm 4.00$ ppm; Bond and Lavers, 2011) from adult birds exceeds the hypothesized toxic effect level (5 ppm; Burger, 1993) and are among the highest values recorded for any seabird.

\section{Entanglement Records of Flesh-Footed Shearwaters}

Flesh-footed Shearwaters are frequently caught in commercial and recreational fishing debris, including nets and line (Abraham et al., 2010; Reid et al., 2012, 2013). These types of interactions are typically documented as fisheries by-catch (incidental take) as the gear is in active use or recently discarded (i.e., the bird was cut free with gear still attached). Entanglements in fishing gear that was discarded long-ago (i.e., mortality attributed to marine debris, not by-catch) and other types of debris (e.g., balloons, 
plastic bags) are more difficult to quantify, and are therefore underestimated, as the data are based on anecdotal accounts spread over a wide geographic area. Published records of Fleshfooted Shearwaters entangled in marine debris do not exist, but have been documented by the public (Figure 3).

\section{AUSTRALIAN CETACEANS AND MEDITERRANEAN SEABIRDS}

The two regions investigated in this review face similar threats, however the Mediterranean has benefitted from substantially more research on cetaceans, probably due to being surrounded by more countries/people and involving several different research institutions. In contrast, only a handful of studies are available on cetacean-debris interactions in Australia, with most data derived secondarily from studies focused on diet. Only one report documented the ingestion of small pieces of plastic material by sperm whales (Evans and Hindell, 2004). The Australian Government's Threat Abatement Plan (TAP) for marine debris documented significant numbers of cetacean entanglements in Australian waters between 1998 and 2008, unfortunately these interactions were attributed to fishing nets of unknown status (active or derelict) (Ceccarelli, 2009). As a result, it is not always clear whether these interactions should be classified as by-catch (fishing gear was active at the time of the interaction) or marine debris (inactive gear).

Remarkably, only one study has been published on seabird-plastic interactions in the Mediterranean basin which suggests $70-94 \%$ of shearwaters, $13-50 \%$ of gulls, $13 \%$ of Northern Gannets Morus bassanus, and 50\% of Great Skua Catharacta skua contain plastic debris (Codina-García et al., 2013).

Seabirds and cetaceans may have a key role to informing society about the health of the oceans. In the Mediterranean Sea, cetaceans have provided valuable data as well as in Australia data on seabirds is strong, but the data should be enhanced by considering also seabirds and cetaceans in the two areas, respectively. This lack of data, underline the need to further target research efforts in the areas to understand the magnitude of the issue of plastic pollution on seabirds and cetaceans in the Australian and Mediterranean waters.

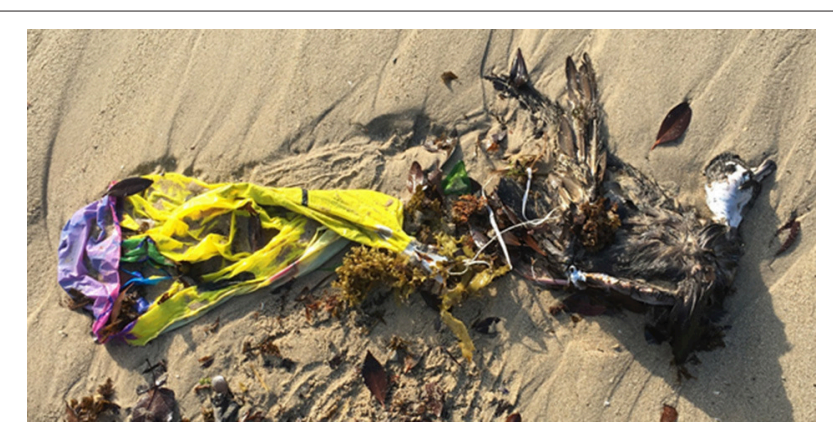

FIGURE 3 | Adult Flesh-footed Shearwater entangled in a mylar foil balloon, Coogee Beach, New South Wales, 7 April 2018 (photo credit: Marina DeBris).

\section{THE “MULTIPLE-STRESS” CONCEPT}

Seabirds and marine mammals are exposed to a variety of adversities that potentially decrease their survival or reproductive success. These include weather, food shortages, predators, competitors, parasites, disease, and human-induced effects (Fair and Becker, 2000; Weimerskirch, 2002). Each factor affects seabirds and marine mammals in a different way, but more importantly, factors can also interact and create impacts far greater than any one factor alone (Burger and Gochfield, 1994; Dirzo et al., 2014). For example, the cumulative impact of mortality from hunting, oiling, predation, and habitat destruction is reducing the ability of many sub-Arctic seabird populations to grow, leaving populations with little room to buffer against increased mortality in poor years (Piatt and Naslund, 1995; Wiese et al., 2004; Lavers et al., 2008). In remote parts of the Southern Ocean, other seabirds don't appear to be experiencing any less pressure. For example, the highly constrained foraging range of penguins (compared to the Procellariiformes) means the health of these birds mirror local conditions. Recent data suggest pollution, habitat loss, fishing, and climate change are all critical threats to penguin populations (Finger et al., 2015; Trathan et al., 2015).

These same anthropogenic pressures are potentially affecting the population stability of cetaceans and other large marine organisms in the Mediterranean Sea where areas with high species diversity overlap with areas that suffer cumulative anthropogenic threats (Coll et al., 2012). Analyzing persistent bioaccumulative and toxic chemicals (e.g., DDT, PCBs), diagnostic markers of exposure to anthropogenic contaminants (e.g., protein and gene expression levels of cytochrome P450) and the genetic variation using microsatellite markers, a statistical model revealed that, among three different subpopulations of striped dolphin, an association between genetic diversity and toxicological stress exists, confirming genetic variability is linked to resilience (Panti et al., 2011; Fossi et al., 2013). Dolphins with lower heterozygosis exhibited significantly higher contaminant loads (50\% originated from the Pelagos Sanctuary). Application of the model provided an outline of the toxicological status of striped dolphin populations and represented a potential tool for the monitoring and conservation of cetacean biodiversity and their habitats. These results underline that in areas where several anthropogenic activities place pressure on populations, top predators are exposed to multiple stressors including plastic pollution, and these species may function as useful sentinels of the consequences for the food chain and human health.

Another example of cumulative stress in Mediterranean cetaceans comes from a recent mass stranding of seven sperm whales along the Adriatic coast (Mazzariol et al., 2011). Necropsy suggested a plethora of different pressure may have caused the mass stranding. Sperm whales presented lymphoid cell depletion acute opportunistic bacterial infections of the respiratory tract T. gondii was detected within a wide range of tissue. Concerning the chemical analysis the total hepatic and renal mercury concentrations, were higher than those measured in sperm whales involved in other mass strandings and also the levels of PCBs and DDT metabolites in tissue samples from of all the 
seven whales. The analysis of the stomach content highlight the presence of different parasites and debris, including fishing gear and hooks, rope, and several plastic items (Mazzariol et al., 2011).

\section{CONCLUSIONS}

The Australian and Mediterranean case studies presented here emphasize the need to consider other species and multiple sources of mortality (by-catch, ship strikes, zoonosis, etc.) when developing management plans for the conservation of ecosystems and biodiversity. For marine debris, there is currently a lack of evidence of impact at the level of the population (Rochman et al., 2016) for all but a handful of species (an exception is Lavers et al., 2014 where ingestion of debris is thought to reduce juvenile survival by $\sim 11 \%$ ). Across species, if factors driving populations trends are not identified or are ignored, effort may be concentrated on sources of mortality which are not the most crucial for the population, resulting in ineffective mitigation. While most anthropogenic pressures on the marine environment are increasing in scope and severity, for some species, the removal of certain threats has been offset by increased pressure from another emerging on the scene. This appears to be the case for Australia's Fleshfooted Shearwater, with populations continuing to decline despite significant reductions in domestic bycatch (Reid et al., 2012). The impacts of lastic debris and associated chemicals are now thought to be driving population trends, at least on Lord Howe Island (Lavers et al., 2014). This outcome

\section{REFERENCES}

Abraham, E. R., Berkenbusch, K. N., and Richard, Y. (2010). The Capture of Seabirds and Marine Mammals in New Zealand Non-commercial Fisheries. New Zealand Aquatic Environment and Biodiversity Report No. 64.

Bakir, A., O'Connor, I. A., Rowland, S. J., Hendriks, A. J., and Thompson, R. C. (2016). Relative importance of microplastics as a pathway for the transfer of hydrophobic organic chemicals to marine life. Environ. Pollut. 219, 56-65. doi: 10.1016/j.envpol.2016.09.046

Baulch, S., and Perry, C. (2014). Evaluating the impacts of marine debris on cetaceans. Mar. Pollut. Bull. 80, 210-221. doi: 10.1016/j.marpolbul.2013.12.050

Besseling, E., Foekema, E. M., Van Franeker, J. A., Leopold, M. F., Kühn, S., Bravo Rebolledo, E. L., et al. (2015). Microplastic in a macro filter feeder: humpback whale megaptera novaeangliae. Mar. Pollut. Bull. 95, 248-252. doi: 10.1016/j.marpolbul.2015.04.007

BirdLife International and National Audubon Society (eds.). (2015). The Messengers: What Birds Tell Us About Threats From Climate Change and Solutions for Nature and People. Cambridge, UK: BirdLife International.

Bond, A. L., and Lavers, J. L. (2011). Trace element concentrations in feathers of flesh-footed shearwaters (Puffinus carneipes) from across their breeding range. Arch. Environ. Contam. Toxicol. 61, 318-326. doi: 10.1007/s00244-010-9605-3

Bossart, G. D. (2011). Marine mammals as sentinel species for oceans and human health. Vet. Pathol. 48, 676-690. doi: 10.1177/0300985810388525

Bottrill, M. C., Joseph, L. N., Carwardine, J., Bode, M., Cook, C., Game, E. T., et al. (2009). Finite conservation funds mean triage is unavoidable. Trends Ecol. Evol. 24, 183-184. doi: 10.1016/j.tree.2008.11.007

Burger, J. (1993). Metals in avian feathers: bioindicators of environmental pollution. Rev. Environ. Toxicol. 5, 203-311.

Burger, J., and Gochfeld, M. (2004). Marine birds as sentinels of environmental pollution. EcoHealth 1, 263-274. doi: 10.1007/s10393-004-0096-4

Burger, J., and Gochfield, M. (1994). "Predation and effects of humans on islandnesting seabirds," in Seabirds on Islands: Threats, Case Studies, and Action Plans, highlights the importance of continually re-assessing parameters of highest importance when managing wild species (Bottrill et al., 2009).

\section{AUTHOR CONTRIBUTIONS}

MF coordinated the manuscript, put together the different scientists and wrote the manuscript. CP wrote, commented on and edited the manuscript. MB wrote, commented on and made the figures. JL wrote and proof-edited the paper.

\section{ACKNOWLEDGMENTS}

JL received financial support for aspects of the research summarized here from L. Bryce, C. Noone, the Detached Foundation, and Trading Consultants Ltd. All seabird research was completed under permit (University of Tasmania Animal Ethics; New South Wales Office of Environment and Heritage; Western Australian Dept. of Biodiversity, Conservation and Attractions; Australia Bird and Bat Banding Service) with generous support from A. Bond, I. Hutton, the Lord Howe Island community, graduate students and volunteers. The fin whale Mediterranean project was supported by the Italian Ministry of Environment, Territory and Sea (prot n. 39752/III-17). Authors want to thank all the authors involved in the studies on cetaceans and seabirds conducted in the Mediterranean and Tasman Sea presented in the present paper.

Proceedings of the Seabird Specialist Group Workshop, eds eds D. N. Nettleship, J. Burger, and M. Gochfield, Birdlife Conservation Series No. 1. University of Waikato (Hamilton).

Cairns, D. K. (1988). Seabirds as indicators of marine food supplies. Biol. Oceanogr. $5,261-271$

Carey, M. J. (2011). Intergenerational transfer of plastic debris by Short-tailed Shearwaters (Ardenna tenuirostris). Emu Austral. Ornithol. 111, 229-234. doi: 10.1071/MU10085

Ceccarelli, D. M. (2009). Impacts of plastic debris on australian marine wildlife in C\&R Consulting. Report by C\&R Consulting for the Department of the Environment, Water, Heritage and the Arts.

Codina-García, M., Militão, T., Moreno, J., and González-Solís, J. (2013). Plastic debris in mediterranean seabirds. Mar. Pollut. Bull. 77, 220-226. doi: 10.1016/j.marpolbul.2013.10.002

Coll, M., Piroddi, C., Albouy, C., Ben Rais Lasram, F., Cheung, W. W. L., Christensen, V., et al. (2012). The mediterranean sea under siege: spatial overlap between marine biodiversity, cumulative threats and marine reserves: the mediterranean sea under siege. Glob. Ecol. Biogeogr. 21, 465-480. doi: 10.1111/j.1466-8238.2011.00697.x

Collignon, A., Hecq, J.-H., Galgani, F., Collard, F., and Goffart, A. (2014). Annual variation in neustonic micro- and meso-plastic particles and zooplankton in the Bay of Calvi (Mediterranean-Corsica). Mar. Pollut. Bull. 79, 293-298. doi: 10.1016/j.marpolbul.2013.11.023

Cózar, A., Echevarría, F., González-Gordillo, J. I., Irigoien, X., Ubeda, B., Hernández-León, S., et al. (2014). Plastic debris in the open ocean. Proc. Natl. Acad. Sci. 111, 10239-10244. doi: 10.1073/pnas.1314 705111

Cózar, A., Sanz-Martín, M., Martí, E., González-Gordillo, J. I., Ubeda, B., Gálvez, J. Á., et al. (2015). Plastic accumulation in the mediterranean sea. PLoS ONE 10:e0121762. doi: 10.1371/journal.pone.0121762

Darmon, G., Miaud, C., Claro, F., Doremus, G., and Galgani, F. (2017). Risk assessment reveals high exposure of sea turtles to marine debris in French 
mediterranean and metropolitan atlantic waters. Deep Sea Res. II Top. Stud. Oceanogr. 141, 319-328. doi: 10.1016/j.dsr2.2016.07.005

de Stephanis, R., Giménez, J., Carpinelli, E., Gutierrez-Exposito, C., and Cañadas, A. (2013). As main meal for sperm whales: plastics debris. Mar. Pollut. Bull. 69, 206-214. doi: 10.1016/j.marpolbul.2013.01.033

Dirzo, R., Young, H. S., Galetti, M., Ceballos, G., Isaac, N. J. B., and Collen, B. (2014). Defaunation in the anthropocene. Science 345, 401-406. doi: $10.1126 /$ science. 1251817

Donnelly-Greenan, E. L., Harvey, J. T., Nevins, H. M., Hester, M. M., and Walker, W. A. (2014). Prey and plastic ingestion of pacific northern fulmars (Fulmarus glacialis rogersii) from monterey bay, california. Mar. Pollut. Bull. 85, 214-224. doi: 10.1016/j.marpolbul.2014.05.046

Durant, J., Hjermann, D., Frederiksen, M., Charrassin, J., Le Maho, Y., Sabarros, P., et al. (2009). Pros and cons of using seabirds as ecological indicators. Clim. Res. 39, 115-129. doi: 10.3354/cr00798

Evans, K., and Hindell, M. (2004). The diet of sperm whales (Physeter macrocephalus) in southern Australian waters. ICES J. Mar. Sci. 61, 1313-1329. doi: 10.1016/j.icesims.2004.07.026

Fair, P. A., and Becker, P. R. (2000). Review of stress in marine mammals. J. Aquat. Ecosyst. Stress Recovery 7, 335-354. doi: 10.1023/A:1009968113079

Finger, A., Lavers, J. L., Dann, P., Nugegoda, D., Orbell, J. D., Robertson, B., et al. (2015). The little penguin (Eudyptula minor) as an indicator of coastal trace metal pollution. Environ. Pollut. 205, 365-377. doi: 10.1016/j.envpol.2015.06.022

Fossi, M. C., Coppola, D., Baini, M., Giannetti, M., Guerranti, C., Marsili, L., et al. (2014). Large filter feeding marine organisms as indicators of microplastic in the pelagic environment: the case studies of the mediterranean basking shark (Cetorhinus maximus) and fin whale (Balaenoptera physalus). Mar. Environ. Res. 100, 17-24. doi: 10.1016/j.marenvres.2014.02.002

Fossi, M. C., Marsili, L., Baini, M., Giannetti, M., Coppola, D., Guerranti, C., et al. (2016). Fin whales and microplastics: the Mediterranean Sea and the Sea of Cortez scenarios. Environ. Pollut. 209, 68-78. doi: 10.1016/j.envpol.2015.11.022

Fossi, M. C., and Panti, C. (2017). Sentinel Species of Marine Ecosystems. Interactive Factory. doi: 10.1093/acrefore/9780199389414.013.110

Fossi, M. C., Panti, C., Baini, M., and Baulch, S. (2018a). "Impacts of marine litter on cetaceans: a focus on plastic pollution," in Marine Mammal Ecotoxicology: Impacts of Multiple Stressors on Population Health, eds M. C. Fossi and C. Panti (Elsevier Academic Press), 416.

Fossi, M. C., Panti, C., Guerranti, C., Coppola, D., Giannetti, M., Marsili, L., et al. (2012). Are baleen whales exposed to the threat of microplastics? A case study of the Mediterranean fin whale (Balaenoptera physalus). Mar. Pollut. Bull. 64, 2374-2379. doi: 10.1016/j.marpolbul.2012.08.013

Fossi, M. C., Panti, C., Marsili, L., Maltese, S., Spinsanti, G., Casini, S., et al. (2013). The pelagos sanctuary for mediterranean marine mammals: marine protected area (MPA) or marine polluted area? The case study of the striped dolphin (Stenella coeruleoalba). Mar. Pollut. Bull. 70, 64-72. doi: 10.1016/j.marpolbul.2013.02.013

Fossi, M. C., Pedà, C., Compa, M., Tsangaris, C., Alomar, C., Claro, F., et al. (2018b). Bioindicators for monitoring marine litter ingestion and its impacts on Mediterranean biodiversity. Environ. Pollut. 237, 1023-1040. doi: 10.1016/j.envpol.2017.11.019

Fossi, M. C., Romeo, T., Baini, M., Panti, C., Marsili, L., Campani, T., et al. (2017). Plastic debris occurrence, convergence areas and fin whales feeding ground in the mediterranean marine protected area pelagos sanctuary: a modeling approach. Front. Mar. Sci. 4, 1-15. doi: 10.3389/fmars.2017.00167

Fossi, M., and Marsili, L. (1997). The use of nondestructive biomarkers in the study of marine mammals. Biomarkers 2, 205-216. doi: 10.1080/135475097231571

Furness, R. (1997). Seabirds as monitors of the marine environment. ICES J. Mar. Sci. 54, 726-737. doi: 10.1006/jmsc. 1997.0243

Gall, S. C., and Thompson, R. C. (2015). The impact of debris on marine life. Mar. Pollut. Bull. 92, 170-179. doi: 10.1016/j.marpolbul.2014.12.041

GESAMP (2016). "Sources, fate and effects of microplastics in the marine environment: part two of a global assessment," in IMO/FAO/UNESCOIOC/UNIDO/WMO/IAEA/UN/ UNEP/UNDP Joint Group of Experts on the Scientific Aspects of Marine Environmental Protection, eds P. J. Kershaw and C. M. Rochman, Reports and Studies GESAMP No. 93.

Goldbogen, J., Pyenson, N., and Shadwick, R. (2007). Big gulps require high drag for fin whale lunge feeding. Mar. Ecol. Prog. Ser. 349, 289-301. doi: $10.3354 /$ meps07066
Gutow, L., Eckerlebe, A., Giménez, L., and Saborowski, R. (2016). Experimental evaluation of seaweeds as a vector for microplastics into marine food webs. Environ. Sci. Technol. 50, 915-923. doi: 10.1021/acs.est. $5 \mathrm{~b} 02431$

Howell, N., Lavers, J. L., Paterson, D., Garrett, R., and Banati, R. (2012). Trace metal distribution in feathers from migratory, pelagic birds using high-resolution synchrotron X-ray fluorescence microscopy. ANSTO Res. Sel. 41-44. Available online at: http://apo.ansto.gov.au/dspace/bitstream/10238/4435/1/Res_Select_ 2012_FINAL_lores_2[1].pdf\#page $=45$

Howell, N., Lavers, J. L., Howard, D., DeJonge, M., Puskar, L., and Banati, R. (2014). "Elemental heterogeneity of degrading plastic debris in the marine environment," in 12th International Conference on X-Ray Microscopy (Melbourne, VIC), 328.

Howell, N. R., Lavers, J. L., Uematsu, S., Paterson, D., Howard, D. L., Spiers, K., et al. (2017). The topobiology of chemical elements in seabird feathers. Sci. Rep. 7:1998. doi: 10.1038/s41598-017-01878-y

IWC, (2013). Report of the IWC Scientific Committee Workshop on Marine Debris.

Jacobsen, J. K., Massey, L., and Gulland, F. (2010). Fatal ingestion of floating net debris by two sperm whales (Physeter macrocephalus). Mar. Pollut. Bull. 60, 765-767. doi: 10.1016/j.marpolbul.2010.03.008

Jenssen, B. M. (2005). Endocrine-disrupting chemicals and climate change: a worst-case combination for arctic marine mammals and seabirds? Environ. Health Perspect. 114, 76-80. doi: 10.1289/ehp.8057

Kühn, S., Rebolledo, E. L. B., and Franeker, J. A., van (2015). "Deleterious effects of litter on marine life," in Marine Anthropogenic Litter, eds M. Bergmann, L. Gutow, and M. Klages (Springer International Publishing), 75-116. doi: 10.1007/978-3-319-16510-3

Laist, D. W. (1997). "Impacts of marine debris: entanglement of marine life in marine debris including a comprehensive list of species with entanglement and ingestion records," in Marine Debris, eds J. M. Coe and D. B. Rogers (New York, NY: Springer), 99-139.

Lavers, J. L. (2015). Population status and threats to Flesh-footed Shearwaters (Puffinus carneipes) in South and Western Australia. ICES J. Mar. Sci. 72, 316-327. doi: 10.1093/icesjms/fsul64

Lavers, J. L., and Bond, A. L. (2016). Selectivity of flesh-footed shearwaters for plastic colour: evidence for differential provisioning in adults and fledglings. Mar. Environ. Res. 113, 1-6. doi: 10.1016/j.marenvres.2015.10.011

Lavers, J. L., Bond, A. L., and Hutton, I. (2014). Plastic ingestion by flesh-footed shearwaters (Puffinus carneipes): implications for fledgling body condition and the accumulation of plastic-derived chemicals. Environ. Pollut. 187, 124-129. doi: 10.1016/j.envpol.2013.12.020

Lavers, J. L., Jones, I. L., Diamond, A. W., and Robertson, G. J. (2008). Annual survival of north american razorbills (Alca torda) varies with ocean climate indices. Can. J. Zool. 86, 51-61. doi: 10.1139/Z07-113

Lewis, P. (2016). Persistent Organic Pollutant (POP) concentrations and plastic loads in Australian Flesh-footed (Ardenna carneipes) and Wedge-tailed Shearwaters (A. pacificus). Honours thesis, RMIT University, Melbourne.

Lusher, A. L., Hernandez-Milian, G., Berrow, S., Rogan, E., and O'Connor, I. (2018). Incidence of marine debris in cetaceans stranded and bycaught in ireland: recent findings and a review of historical knowledge. Environ. Pollut. 232, 467-476. doi: 10.1016/j.envpol.2017.09.070

Lusher, A. L., Hernandez-Milian, G., O'Brien, J., Berrow, S., O'Connor, I., and Officer, R. (2015). Microplastic and macroplastic ingestion by a deep diving, oceanic cetacean: the true's beaked whale mesoplodon mirus. Environ. Pollut. 199, 185-191. doi: 10.1016/j.envpol.2015.01.023

Massos, A., and Turner, A. (2017). Cadmium, lead and bromine in beached microplastics. Environ. Pollut. 227, 139-145. doi: 10.1016/j.envpol.2017.04.034

Mato, Y., Isobe, T., Takada, H., Kanehiro, H., Ohtake, C., and Kaminuma, T. (2001). Plastic resin pellets as a transport medium for toxic chemicals in the marine environment. Environ. Sci. Technol. 35, 318-324. doi: $10.1021 /$ es 0010498

Mattsson, K., Ekvall, M. T., Hansson, L.-A., Linse, S., Malmendal, A., and Cedervall, T. (2015). Altered behavior, physiology, and metabolism in fish exposed to polystyrene nanoparticles. Environ. Sci. Technol. 49, 553-561. doi: $10.1021 /$ es5053655

Mattsson, K., Johnson, E. V., Malmendal, A., Linse, S., Hansson, L.-A., and Cedervall, T. (2017). Brain damage and behavioural disorders in fish induced by plastic nanoparticles delivered through the food chain. Sci. Rep. 7:11452. doi: $10.1038 / s 41598-017-10813-0$ 
Mazzariol, S., Guardo, G. D., Petrella, A., Marsili, L., Fossi, C. M., Leonzio, C., et al. (2011). Sometimes sperm whales (Physeter macrocephalus) cannot find their way back to the high seas: a multidisciplinary study on a mass stranding. PLoS ONE 6:e19417. doi: 10.1371/journal.pone.0019417

Moore, C., Moore, S., Leecaster, M., and Weisberg, S. (2001). A comparison of plastic and plankton in the north pacific central gyre. Mar. Pollut. Bull. 42, 1297-1300. doi: 10.1016/S0025-326X(01)00114-X

Moore, M. J., Andrews, R., Austin, T., Bailey, J., Costidis, A., George, C., et al. (2013). Rope trauma, sedation, disentanglement, and monitoringtag associated lesions in a terminally entangled North Atlantic right whale (Eubalaena glacialis). Mar. Mammal Sci. 29, E98-E113. doi: 10.1111/j.1748-7692.2012.00591.x

Panti, C., Giannetti, M., Baini, M., Rubegni, F., Minutoli, R., and Fossi, M. C. (2015). Occurrence, relative abundance and spatial distribution of microplastics and zooplankton NW of sardinia in the pelagos sanctuary protected area, mediterranean sea. Environ. Chem. 12, 618. doi: 10.1071/EN14234

Panti, C., Spinsanti, G., Marsili, L., Casini, S., Frati, F., and Fossi, M. C. (2011). Ecotoxicological diagnosis of striped dolphin (Stenella coeruleoalba) from the Mediterranean basin by skin biopsy and gene expression approach. Ecotoxicology 20, 1791-1800. doi: 10.1007/s10646-011-0713-2

Pedà, C., Caccamo, L., Fossi, M. C., Gai, F., Andaloro, F., Genovese, L., et al. (2016). Intestinal alterations in European sea bass Dicentrarchus labrax (Linnaeus, 1758) exposed to microplastics: preliminary results. Environ. Pollut. 212, 251-256. doi: 10.1016/j.envpol.2016.01.083

Pedrotti, M. L., Petit, S., Elineau, A., Bruzaud, S., Crebassa, J.-C., Dumontet, B., et al. (2016). Changes in the floating plastic pollution of the mediterranean sea in relation to the distance to land. PLOS ONE 11:e0161581. doi: 10.1371/journal.pone.0161581

Piatt, J. F., and Naslund, N. L. (1995). Abundance, distribution, and Population status of Marbled Murrelets in Alaska. USDA Forest Service General Technical Report PSW-152.

Poloczanska, E. S., Brown, C. J., Sydeman, W. J., Kiessling, W., Schoeman, D. S., Moore, P. J., et al. (2013). Global imprint of climate change on marine life. Nat. Clim. Change 3, 919-925. doi: 10.1038/nclimate1958

Rani, M., Shim, W. J., Han, G. M., Jang, M., Al-Odaini, N. A., Song, Y. K., et al. (2015). Qualitative analysis of additives in plastic marine debris and its new products. Arch. Environ. Contam. Toxicol. 69, 352-366. doi: 10.1007/s00244-015-0224-x

Reid, T. (2010). Modelling the Foraging Ecology of the Flesh-footed Shearwater Puffinus Carneipes in Relation to Fisheries and Oceanography. Ph.D. thesis, University of Tasmania (Hobart, TAS).

Reid, T., Hindell, M., Lavers, J. L., and Wilcox, C. (2013). Re-examining mortality sources and population trends in a declining seabird: using bayesian methods to incorporate existing information and new data. PLOS ONE 8:e58230. doi: 10.1371/journal.pone.0058230

Reid, T., Hindell, M., and Wilcox, C. (2012). Environmental determinants of the at-sea distribution of encounters between flesh-footed shearwaters Puffinus carniepes and fishing vessels. Mar. Ecol. Prog. Ser. 447, 231-242. doi: 10.3354/meps09449

Rochman, C. M., Browne, M. A., Halpern, B. S., Hentschel, B. T., Hoh, E., Karapanagioti, H. K., et al. (2013). Policy: classify plastic waste as hazardous. Nature 494, 169-171. doi: 10.1038/494169a

Rochman, C. M., Browne, M. A., Underwood, A. J., van Franeker, J. A., Thompson, R. C., and Amaral-Zettler, L. A. (2016). The ecological impacts of marine debris: unraveling the demonstrated evidence from what is perceived. Ecology 97, 302-312. doi: 10.1890/14-2070.1

Rochman, C. M., Parnis, J. M., Browne, M. A., Serrato, S., Reiner, E. J., Robson, M., et al. (2017). Direct and indirect effects of different types of microplastics on freshwater prey (Corbicula fluminea) and their predator (Acipenser transmontanus). PLoS ONE 12:e0187664. doi: 10.1371/journal.pone. 0187664

Rudduck, O.-A., Lavers, J. L., Fischer, A. M., Stuckenbrock, S., Sharp, P. B., and Banati, R. B. (2017). Inter-annual variation in the density of anthropogenic debris in the Tasman Sea. Mar. Pollut. Bull. 124, 51-55. doi: 10.1016/j.marpolbul.2017.07.010

Ryan, P. G. (1987). The incidence and characteristics of plastic particles ingested by seabirds. Mar. Environ. Res. 23, 175-206. doi: 10.1016/0141-1136(87)90028-6

Santana, M. F. M., Moreira, F. T., and Turra, A. (2017). Trophic transference of microplastics under a low exposure scenario: insights on the likelihood of particle cascading along marine food-webs. Mar. Pollut. Bull. 121, 154-159. doi: 10.1016/j.marpolbul.2017.05.061

Schwacke, L. H., Gulland, F. M., and White, S. (2013). "Sentinel Species in Oceans and Human Health," in Environmental Toxicology (New York, NY: Laws E. A.), 503-528.

Setälä, O., Fleming-Lehtinen, V., and Lehtiniemi, M. (2014). Ingestion and transfer of microplastics in the planktonic food web. Environ. Pollut. 185, 77-83. doi: 10.1016/j.envpol.2013.10.013

Sheavly, S. B., and Register, K. M. (2007). Marine debris and plastics: Environmental concerns, sources, impacts and solutions. J. Polym. Environ. 15, 301-305. doi: 10.1007/s10924-007-0074-3

Suaria, G., Avio, C. G., Mineo, A., Lattin, G. L., Magaldi, M. G., Belmonte, G., et al. (2016). The mediterranean plastic soup: synthetic polymers in mediterranean surface waters. Sci. Rep. 6: 37551. doi: 10.1038/srep37551

Sussarellu, R., Suquet, M., Thomas, Y., Lambert, C., Fabioux, C., Pernet, M. E. J., et al. (2016). Oyster reproduction is affected by exposure to polystyrene microplastics. Proc. Natl. Acad. Sci. U.S.A. 113, 2430-2435. doi: 10.1073/pnas.1519019113

Tanaka, K., Takada, H., Yamashita, R., Mizukawa, K., Fukuwaka, M., and Watanuki, Y. (2015). Facilitated leaching of additive-derived PBDEs from plastic by seabirds' stomach oil and accumulation in tissues. Environ. Sci. Technol. 49, 11799-11807. doi: 10.1021/acs.est.5b01376

Trathan, P. N., García-Borboroglu, P., Boersma, D., Bost, C.-A., Crawford, R. J. M., Crossin, G. T., et al. (2015). Pollution, habitat loss, fishing, and climate change as critical threats to penguins: primary threats to penguins. Conserv. Biol. 29, 31-41. doi: $10.1111 /$ cobi.12349

UNEP/MAP, (2015). Marine Litter Assessment in the Mediterranean. Athens: UNEP/MAP.

van der Hoop, J., Moore, M., Fahlman, A., Bocconcelli, A., George, C., Jackson, K., et al. (2014). Behavioral impacts of disentanglement of a right whale under sedation and the energetic cost of entanglement. Mar. Mammal Sci. 30, 282-307. doi: $10.1111 / \mathrm{mms} .12042$

van Franeker, J. A., Bravo Rebolledo, E. L., Hesse, E., IJsseldijk, L. L., Kühn, S., Leopold, M., et al. (2018). Plastic ingestion by harbour porpoises phocoena phocoena in the Netherlands: establishing a standardised method. Ambio 47, 387-397. doi: 10.1007/s13280-017-1002-y

van Franeker, J. A., and Law, K. L. (2015). Seabirds, gyres and global trends in plastic pollution. Environ. Pollut. 203, 89-96. doi: 10.1016/j.envpol.2015.02.034

Verlis, K. M., Campbell, M. L., and Wilson, S. P. (2013). Ingestion of marine debris plastic by the wedge-tailed shearwater Ardenna pacifica in the great barrier reef, australia. Mar. Pollut. Bull. 72, 244-249. doi: 10.1016/j.marpolbul.2013.03.017

Weimerskirch, H. (2002). "Seabird demography and its relationship with the marine environment," in Biology of Marine Birds, eds E. A. Schreiber and J. Burger (Boca Raton, FL: CRC Press), 115-135.

Wiese, F. K., Robertson, G. J., and Gaston, A. J. (2004). Impacts of chronic marine oil pollution and the murre hunt in Newfoundland on thick-billed murre Uria lomvia populations in the eastern Canadian Arctic. Biol. Conserv. 116, 205-216. doi: 10.1016/S0006-3207(03)00191-5

Young, L. C., Vanderlip, C., Duffy, D. C., Afanasyev, V., and Shaffer, S. A. (2009). Bringing home the trash: do colony-based differences in foraging distribution lead to increased plastic ingestion in laysan albatrosses? PLoS ONE 4:e7623. doi: 10.1371/journal.pone.0007623

Zacharias, M. A., and Roff, J. C. (2001). Use of focal species in marine conservation and management: a review and critique. Aquat. Conserv. Mar. Freshw. Ecosyst. 11, 59-76. doi: 10.1002/aqc.429

Conflict of Interest Statement: The authors declare that the research was conducted in the absence of any commercial or financial relationships that could be construed as a potential conflict of interest.

The reviewer MFC and handling Editor declared their shared affiliation.

Copyright (๑) 2018 Fossi, Panti, Baini and Lavers. This is an open-access article distributed under the terms of the Creative Commons Attribution License (CC $B Y)$. The use, distribution or reproduction in other forums is permitted, provided the original author(s) and the copyright owner are credited and that the original publication in this journal is cited, in accordance with accepted academic practice. No use, distribution or reproduction is permitted which does not comply with these terms. 